Journal of Engineering and Applied Sciences 14 (Special Issue 3): 6085-6088, 2019

ISSN: 1816-949X

(C) Medwell Journals, 2019

\title{
Relationship Between Compressive Strength and Ultra-Sonic Pulse Velocity (UPV) of Local Fly Ash Concrete
}

\author{
${ }^{1,2} \mathrm{Jamil}$ Matarul, ${ }^{1} \mathrm{Chiew}$ Fei Ha, ${ }^{3} \mathrm{Md}$. Abdul Mannan, ${ }^{1}$ Azmi Ibrahim and ${ }^{1}$ Ezze Elma binti Mohd. Yusof \\ ${ }^{1}$ Faculty of Civil Engineering, Universiti Teknologi MARA, 94300 Kota Samarahan, \\ Sarawak, Malaysia \\ ${ }^{2}$ Department of Civil Engineering, Faculty of Engineering, Universiti Malaysia Sarawak, \\ 94300 Kota Samarahan, Sarawak, Malaysia \\ ${ }^{3}$ Faculty of Civil Engineering, Universiti Teknologi MARA, 404500 Shah Alam, Selangor, Malaysia \\ Jamsrul@gmail.com
}

\begin{abstract}
Non-destructive method monitoring or service life prediction of concrete structures is becoming crucial interest to engineers. The good conceptual understanding between non-destructive method and destructive method is essential to ensure that optimum concrete performance is achieved before a costly repair to the structure becomes necessary. This study was conducted to determine the relationship between the compressive strength and the Ultra-sonic Pulse Velocity (UPV) on the concrete partially replaces the cement content (by mass percentages) with local fly ash. Furthermore, $\mathrm{R}^{2}$ was indicating the advantages of UPV against compressive strength. The experiment was investigated using grade concrete of G35 and G45 supplied by local ready mixed concrete in Kuching Sarawak. The cement content for each concrete grade was replaced with fly ash about $10 \%$ percentage increment from $20-60 \%$. Waste material (Fly ash) used as cementitious material were collected from single main local supplier in Pending Sarawak. The specimens used in the studies were made of $150 \mathrm{~mm}$ concrete cube. Specimens tested for UPV then followed by compressive strength at the age of 14, 28, 56,90 and 180 days. In which curing age extended to 56 and 90 days to participated delay setting time of ready mixed concrete enhance by fly ash. Meanwhile, 180 days conducted for long term correlation between compressive strength and UPV purpose. Based on the compressive strength and UPV tests conducted in both concrete grades, clear linear regression relationship was drawn to describe highly agreement between two parameters measured. Compressive strength vs. UPV correlation curves were recorded $\mathrm{R}^{2}$ values of 0.776 and 0.807 for G35 and G45, respectively. Therefore, the higher values of $\mathrm{R}^{2}$ indicate using UPV as non-destructive method was develops greater confidence to replace destructive method (compressive strength) for long term strength monitoring with fastest and low cost testing method.
\end{abstract}

Key words: Ultra-sonic pulse velocity, fly ash, ready mixed concrete, non-destructive test, strength monitoring, compressive strength

\section{INTRODUCTION}

There is a growing interest at an international level in non-destructive testing of cement based materials such as Ultrasonic Pulse Velocity (UPV), Rebound Hammer (RH) and etc. The UPV test is frequently used in order to estimate the quality of concrete by transmitting an irrational pulse to travel at known distances (Long et al., 1945). It is usually very helpful in detecting the presence of cracks in a structural (Kar et al., 2013). Includes assessing the durability where amplitude, velocity and frequency variations depending on the age of the material can be observed during the hardening process. Based on previous studies, there is a good correlation between UPV and the compressive strength of concrete (Sounthararajan and Sivakumar, 2012). The correlation, however is not unique but rather depends particularly on the mix proportions, cement type and type of aggregate used (Panzera et al., 2011). Moreover, there is some study also concluded that if the UPV is measured at different locations in a structure, the compressive strength values can be predicted (Kar et al., 2013). Moreover, this method has been shown for some time in providing a reliable means of estimating properties and offers a unique

Corresponding Author: Jamil Matarul, Faculty of Civil Engineering, Universiti Teknologi MARA, 94300 Kota Samarahan, Sarawak, Malaysia, Jamsrul@gmail.com 
opportunity for direct, reliable, quick, safe, inexpensive and non-invasive quality control of buildings and other concrete constructions damaged by earthquake, fatigue, conflagration or the other catastrophic scenarios (Panzera et al., 2011).

Besides, a good number of studies were conducted to monitor the strength gained on concrete with a particular cement replacement such as fly ash, silica fume and slag (Kar et al., 2013; Ramana et al., 2016). The beneficial use of fly ash in concrete has increased the interest of researcher for the evaluation of the performance of such concrete exposed to various aggressive environments (Islam et al., 2018). In addition, the use of fly ash to replace a portion of the cement resulted in significant savings in cost production of concrete (Saraswathy et al., 2003) and environmentally friendly (Islam et al., 2018).

Therefore with all the evidence using nondestructive test of UPV is used widely and greatly in evaluating the strength of concrete and in situ experiment without having the concrete crushed and surely save the cost of construction.

Research significant: This study carried out compressive strength and UPV tests at different grade of concrete cube enhance by local fly ash as waste material. Fly ash was collected from Sejingkat Power Corporation Sdn. Bhd., which is located in Pending Sarawak with annual coal consumption up to 1 million tonnes. Furthermore, the set testing results on cubes are taken to establish a clear relationship between compressive strength and UPV for long term strength monitoring with fast and low cost testing method.

\section{MATERIALS AND METHODS}

Concrete mixes used is adopted from a previous study (Matarul et al., 2016). In which concrete mix design was provided by established concrete ready mixed supplier in Kuching. The existing concrete mixtures were enhanced by replacing the cement content with fly ash of $10 \%$ increment from $10-60 \%$ for two different grades, G35 and G45. The concrete mix designs are shown in Table 1. $150 \mathrm{~mm}$ concrete cubes were used to determine both compressive strength and UPV at the age of 14,28 , 56,90 and 180 days. The UPV tests were performed based on Anonymous (2013) with direct transmission measurement and saturated-surface dry condition. Meanwhile, compressive strength was conducted based on Anonymous (2012).

Table 1: Concrete mix proportions design

\begin{tabular}{lllllll}
$\begin{array}{l}\text { Grade of } \\
\text { concrete }\end{array}$ & $\begin{array}{l}\text { Cement } \\
\left(\mathrm{kg} / \mathrm{m}^{3}\right)\end{array}$ & $\begin{array}{l}\text { Water/ } \\
\text { Cement } \\
\text { ratio }\end{array}$ & $\begin{array}{l}\text { Fine } \\
\text { aggregate } \\
\left(\mathrm{kg} / \mathrm{m}^{3}\right)\end{array}$ & $\begin{array}{l}\text { Coarse } \\
\text { aggregate } \\
\left(\mathrm{kg} / \mathrm{m}^{3}\right)\end{array}$ & $\begin{array}{l}\text { Water } \\
\left(\mathrm{kg} / \mathrm{m}^{3}\right)\end{array}$ & $\begin{array}{l}\text { Slump } \\
(\mathrm{mm})\end{array}$ \\
\hline $\mathrm{G} 35$ & 375 & 0.45 & 756 & 1040 & 170 & 115 \\
$\mathrm{G} 45$ & 422 & 0.35 & 621 & 1284 & 147.6 & 105 \\
\hline
\end{tabular}

\section{RESULTS AND DISCUSSION}

The experimental data discussed in this study and presented in Fig. 1 are generated from two grades of concrete includes with fly ash cement replacements. Both grades are tested for compressive strength and UPV at identifying ages.

Relationship between compressive strength and UPV: Figure 1 shows the correlation between compressive strength and UPV for both concrete grades with a variation of fly ash percentages and curing ages. Figure 1a shows the UPV values range from 3.36-4.56 $\mathrm{km} / \mathrm{sec}$ and only a few values more than $4.5 \mathrm{~km} / \mathrm{sec}$ which is categorize as excellent quality of concrete. Figure $1 \mathrm{~b}$ shows the UPV values range from $3.66-4.62 \mathrm{~km} / \mathrm{sec}$ and not $<10 \%$ of specimens above $4.5 \mathrm{~km} / \mathrm{sec}$ recorded by specimens tested at 56,90 and 180 days. Both linear regressions were clearly recorded good agreement correlation relationship between compressive strength and UPV which $R^{2}$ are 0.776 and 0.807 for the G35 and G45, respectively. This is also proven by other study with $\mathrm{R}^{2}$ value of 0.90 for hardened concrete contain fly ash up to $60 \%$ cement replacement (Makul and Sua-Iam, 2014). Slightly higher $\mathrm{R}^{2}$ which is above 0.95 tested on mineral admixture mortal containing fly ash (Gul et al., 2006). All UPV values increase as the compressive strength of specimen increases and ages increase. Similar finding in previous studies had proven that UPV increased with increasing compressive strength in all of the mixture as the concrete is more good quality in terms of homogeneity, uniformity, density, etc., (Panzera et al., 2011; Kar et al., 2013; Arundas and Dewangan, 2016; Makul and Sua-Iam, 2014).

Verification of proposed UPV-strength correlation linear regression: Proposed UPV-compressive strength relationship were verify by additional specimens prepared by 40 and 30\% fly ash cement replacement to the concrete grades G35 and G45, respectively. Prepared specimens were tested for UPV and compressive strength simultaneously at the age of 28 and 56 days. The measured UPV of each specimen was used to predict its compressive strength by using Eq. 1 and 2 accordingly. Then, the predicted strength was compared with the measured compressive strength obtained by compression machine as shown in Table 2 and 3 . Table 2 shows that comparison results between predicted and actual compressive strength are ranging from -8.55 to $-6.79 \%$ and -2.01 to $2.31 \%$ at ages 28 and 56 days, respectively, for G35. Besides, for G45 the results variances are ranging from -4.91 to $-2.79 \%$ and -1.81 to $7.01 \%$ at ages 28 and 
Table 2: Compressive strength prediction with variance for $\mathrm{G} 35$

\begin{tabular}{llcccc}
\hline Specimen No. & Age & Pulse velocity $(\mathrm{km} / \mathrm{sec})$ & Predicted Cu $(\mathrm{MPa})$ & Actual Cu $(\mathrm{MPa})$ & Variance $(\%)$ \\
\hline 1 & 28 & 4.157 & 48.89 & 53.09 & -7.91 \\
2 & & 4.195 & 50.06 & 53.71 & -6.79 \\
3 & 56 & 4.078 & 46.47 & 50.82 & -8.55 \\
4 & 4.524 & 60.14 & 61.37 & -2.01 \\
5 & & 4.530 & 60.33 & 59.26 & 1.81 \\
6 & & 4.511 & 59.74 & 58.39 & 2.31 \\
\hline
\end{tabular}

Table 3: Compressive strength prediction with variance for $\mathrm{G} 45$

\begin{tabular}{llcccr}
\hline Specimen No. & Age & Pulse velocity $(\mathrm{km} / \mathrm{sec})$ & Predicted Cu $(\mathrm{MPa})$ & Actual Cu $(\mathrm{MPa})$ & Variance $(\%)$ \\
1 & 28 & 4.265 & 53.58 & 56.35 & -4.91 \\
2 & & 4.481 & 61.86 & 63.64 & -2.79 \\
3 & & 4.378 & 57.91 & 60.36 & -4.05 \\
4 & 56 & 4.545 & 64.31 & 60.10 & 7.01 \\
5 & & 4.561 & 64.92 & 66.12 & -1.81 \\
6 & & 4.571 & 65.31 & 61.43 & 6.31 \\
\hline
\end{tabular}
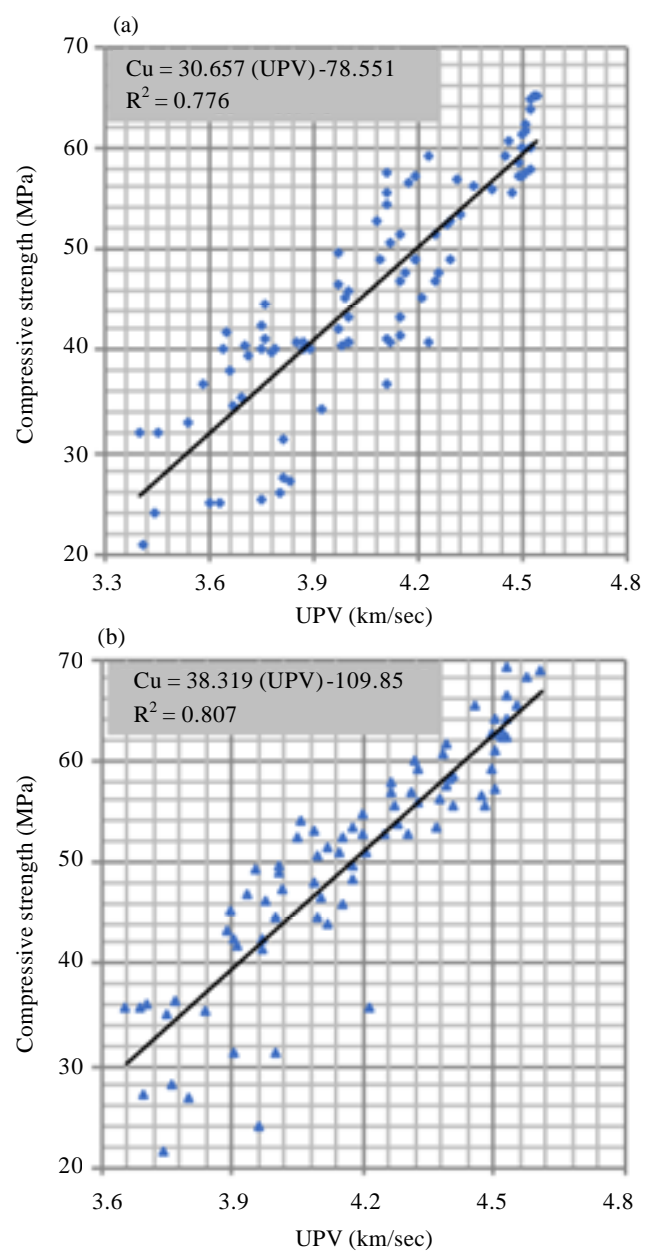

Fig. 1: a) Cu vs. UPV for G35 and b) Cu vs. UPV for G45

56 days, respectively. The UPV result is directly proportional to the compressive strength whereas the porosity decreases in high concrete strength (Makul and
Sua-Iam, 2014). However, at age 56 days, most of the predicted compressive strengths are almost higher than actual. It is due to completely reduce the void space between cement particles in the hardening concrete as well as shortening time of transmitting an irrational pulse for more good quality of concrete:

$$
\begin{aligned}
& \mathrm{Cu}=30.657(\mathrm{UPV})-78.551 \\
& \mathrm{Cu}=38.319(\mathrm{UPV})-109.85
\end{aligned}
$$

\section{CONCLUSION}

The important conclusions arrived based on the experimental investigations summarized below:

- Good agreement correlation relationship recorded between compressive strength and UPV for concrete grade $\mathrm{G} 35$ which is $\mathrm{R}^{2}=0.776$

- Good agreement correlation relationship recorded between compressive strength and UPV for concrete grade $\mathrm{G} 45$ which is $\mathrm{R}^{2}=0.807$

- Proof verification on proposed Eq. 1 for G35 calculated variance ranging from -8.55 to $2.31 \%$

- Proof verification on proposed Eq. 2 for G45 calculated variance ranging from -4.91 to $7.01 \%$

\section{ACKNOWLEDGEMENTS}

The researchers are grateful thanks to Faculty of Civil Engineering, Universiti Teknologi MARA (UiTM) Sarawak, Department of Civil Engineering, Faculty of Engineering, Universiti Malaysia Sarawak (UNIMAS), CMS Concrete Products Sdn. Bhd. and Gobel Industry Sdn. Bhd. for successful completion of this research. 


\section{REFERENCES}

Anonymous, 2012. MS EN 12390-3 Testing hardened concrete-Part 3: Compressive strength of test specimens. Department of Standards Malaysia, Cyberjaya, Malaysia.

Anonymous, 2013. MS EN 12504-4 Testing concrete in structures-Part 4: Determination of ultrasonic pulse velocity. Department of Standards Malaysia, Cyberjaya, Malaysia. http://webcache. googleusercontent. com/search?q=cache:YXpx8RZ RemwJ:www.msonline.gov.my/download_file.php \%3F file\%3D31483\%26source\%3Dproduction+\&cd $=1 \&$ hl $=$ en\&ct $=$ clnk\&gl $=$ pk\&client $=$ firefox $-b$

Arundas, P.H. and U.K. Dewangan, 2016. Compressive strength of concrete based on ultrasonic and impact echo test. Indian J. Sci. Technol., 9: 1-7.

Gul, R., R. Demirboga and T. Guvercin, 2006. Compressive strength and ultrasound pulse velocity of mineral admixture mortals. Indian J. Eng. Mater. Sci., 13: 18-24.

Islam, M., A.K.M. Arifuzzaman, T. Alam and S. Islam, 2018. Durability characteristics of fly ash blended concrete in marine environment. J. Civ. Eng., 46: 53-68.

Kar, A., U.B. Halabe, I. Ray and A. Unnikrishnan, 2013. Nondestructive characterizations of alkali activated fly ash and/or slag concrete. Eur. Sci. J., 9: 52-74.
Long, B.G., H.J. Kurtz and T.A. Sandenaw, 1945. An instrument and a technique for field determination of the modulus of elasticity and flexural strength, of concrete (pavements). Intl. Concr. Abstracts Portal, 41: 217-232.

Makul, N. and G. Sua-Iam, 2014. Self-compacting concrete containing untreated-mixed fly ash and rice husk ash, Part II: Hardened concrete characteristics. Res. Dev. J., 25: 15-24.

Matarul, J., M.A. Mannan, M.Z.M.I. Safawi, A. Ibrahim and N.A. Jainudin et al., 2016. Performance-based durability indicators of different concrete grades made by the local ready mixed company: Preliminary results. Procedia Soc. Behav. Sci., 224: 620-625.

Panzera, T.H., A.L. Christoforo, F.P. Cota, P.H.R. Borges and C.R. Bowen, 2011. Ultrasonic Pulse Velocity Evaluation of Cementitious Materials. In: Advances in Composite Materials-Analysis of Natural and Man-Made Materials, Tesinova, P. (Ed.). IntechOpen, Rijeka, Croatia, ISBN: 978-953-307-449-8, pp: 411-436.

Ramana, V., M. Potharaju, N.V. Mahure and M. Ratnam, 2016. Strength and durability studies of multi blended concretes containing fly ash and silica fume. Indian Concr. J., 90: 53-65.

Saraswathy, V., S. Muralidharan, K. Thangavel and S. Srinivasan, 2003. Influence of activated fly ash on corrosion-resistance and strength of concrete. Cem. Concr. Compos., 25: 673-680.

Sounthararajan, V.M. and A. Sivakumar, 2012. Ultrasonic tests on setting properties of cementitious systems. ARPN. J. Eng. Appl. Sci., 7: 1424-1435. 